\title{
Plasma Membrane Microparticles in Angiogenesis: Role in Ischemic Diseases and in Cancer
}

\author{
H. A. MOSTEFAI, R. ANDRIANTSitohainA, M. C. MARTínez \\ CNRS UMR 6214, INSERM U771, Faculté de Médecine, Université d'Angers, Angers, France
}

Received February 24, 2008

Accepted April 14, 2008

\begin{abstract}
Summary
Microparticles are small fragments of the plasma membrane released by activated and/or apoptotic cells. In theory, all type of cells can shed microparticles representing a physiological process in the cell life. Mainly, microparticles generation has been studied in different cardiovascular pathologies due to the facility to obtain blood samples from individuals. Although microparticles have been considered as simply markers of several diseases, in the last decade, several studies support the hypothesis that they participate in the regulation of the cardiovascular system function by carrying biological messages between cells. Among the effects of microparticles, recent data show that they can be implicated in the modulation of neovascularization, an essential function of cells from cardiovascular system during either ischemic diseases or cancer development. Whereas during pathologies associated with ischemia an increase of neovascularization may have beneficial effects, anti-angiogenic strategies represent new approaches for manipulation of tumor development. Here, we give an overview of the mechanisms and factors involved in neovascularization, and finally, we look at the role and the consequences of the modulation of this process by microparticles in pathological situations.
\end{abstract}

\section{Key words}

Microparticles • Endothelial cells • Ischemic diseases • Tumor development

\section{Corresponding author}

M. Carmen Martínez, CNRS UMR 6214 - INSERM 771, Faculté de Médecine, Rue Haute de Reculée, F-49045, Angers, France. Tel: +332417358 57. E-mail: carmen.martinez@univ-angers.fr

\section{Vasculogenesis, angiogenesis and neovascularization}

There are two distinct but interconnected processes for the formation of postnatal new blood vessels, vasculogenesis and angiogenesis. The former is referred to the formation of the earliest vascular network via the differentiation of endothelial progenitor cells (EPCs) (also called angioblasts) into endothelial cells (ECs) (Asahara et al. 1997). By contrast, angiogenesis consists in the formation of new capillaries from the preexisting vasculature (Carmeliet 2003). Thus, it is largely accepted that vasculogenesis might play a key role in embryogenesis, whereas angiogenesis can take place in both pre- and postnatal life. However, recent evidence suggests that in the adult, also EPCs could be considered as a source of cells that can participate in postnatal vasculogenesis. In addition, a third process, arteriogenesis, which describes the development and growth of pre-existing arterioles into physiological relevant arteries forming collateral vessels (Luque Contreras et al. 2006, Heilsch and Schaper 2003), complete the expansion and growth the vascular system in adults. It is obvious that, in the literature, these three mechanisms involved in the development of the cardiovascular system are frequently confounded and are not mutually exclusive. In this review, we have summarized the mechanisms implicated in in vitro angiogenesis and in the in vivo neovascularization, which takes into account the three processes described above. 


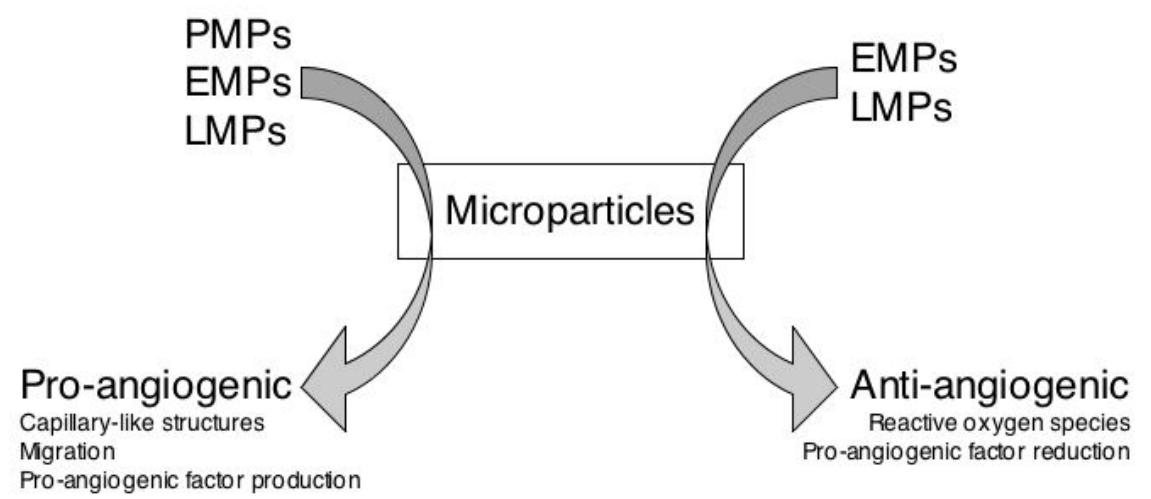

Fig. 1. Differential effects of microparticles on angiogenesis depending on their origin. Microparticles from platelets (PMPs) display pro-angiogenic properties by promoting capillarylike structures and pro-angiogenic factor production. By contrast, both endothelial- and lymphocytederived microparticles (EMPs, LMPs) possess pro- or antiangiogenic properties depending on the stimuli used for their production.

\section{Mechanisms implicated in neovascularization}

\begin{abstract}
Neovascularization plays a key role in physiological processes including embryonic development and wound repair as well as in various pathologies such as ischemic diseases, cancer, diabetic retinopathy or chronic inflammation including atherosclerosis (Folkman 1995). The neovascularization process is matched with changes in tissue mass and/or metabolic demands in order to maintain adequate oxygen delivery. This tightly regulated process involves the degradation of extracellular matrix, disruption of cell-cell contacts, migration and proliferation, and capillary tube formation of ECs. More in detail, angiogenic stimuli cause increased EC permeability through dissolution of adherens junctions (Pepper 2001). Briefly, EC proliferation occurs early in neovascularization, and continues as the new capillary sprout elongates. Proteolysis of basement membrane matrix cellular components is necessary to promote endothelial invasion into the surrounding interstitial matrix. Cellular migration is triggered and the sprouting tip of the EC proceeds into the interstitium. Lumen formation occurs as the sprout forms a multi-cellular structure. The new capillary channel forms an anastomosis with a pre-existing capillary, creating a new patent capillary. The final stage requires stabilization of the capillary through the construction of basement membrane, adherent junctions and cessation of ECs activation.
\end{abstract}

\section{Factors regulating neovascularization}

Normal tissues present a balance between proangiogenic and anti-angiogenic factor productions, however under pathologic conditions, this balance is dysregulated. Stimuli known to initiate neovascularization include hypoxia, inflammation, and mechanical factors such as shear stress and stretch. These stimuli either directly or indirectly activate ECs, by initiating the autocrine or paracrine production and release of growth factors or cytokines. Here, we briefly describe several factors known by their abilities to modulate angiogenesis.

The most important molecule that controls neovascularization is vascular endothelial growth factor (VEGF). Among the different isoforms of VEGF that have been described, VEGFA is the most potent angiogenic factor in vivo. Indeed, VEGFA regulates endothelial proliferation and permeability, as well as chemotaxis and differentiation of EPCs that are the main steps taking place in neo-vascularization (Asahara et al. 1999). In addition, inhibition of VEGFA activity is correlated with reduction of growth of tumors, suggesting that approaches considering inhibition of the VEGF activity could represent successful therapies against cancer. Finally, it has been shown that VEGF induces endothelial nitric oxide synthase (eNOS) expression and nitric oxide (NO) release from ECs (Ziche et al. 1997), which favors the proangiogenic process of capillary formation (Donnini and Ziche 2002). This is accordingly with studies performed in eNOS knockout mice displaying attenuated VEGF and angiogenesis induced by ischemia (Fukumura et al. 2001). Altogether, these data suggest that NO from eNOS as a key mediator of VEGF signaling.

Many other factors regulate the process of neovascularization. Among these, angiopoietins (mainly angiopoietins 1,2 and 4) activate ECs in a paracrine manner resulting in a pro-angiogenic effect. Also, other 
growth factors such as basic fibroblast growth factor (bFGF), platelet-derived growth factor (PDGF) or epidermal growth factor (EGF) display pro-angiogenic properties and induce EC proliferation (Das and Vasudevan 2007). Integrins can affect angiogenesis by mediating the direct interactions between cellular and extracellular matrix proteins (Hsu et al. 2007). Several interleukins (IL), in particular IL-6 and IL-8 are described as pro-angiogenic mediators (Motro et al. 1990, Park et al. 2001).

Anti-angiogenic factors can act directly on the ECs by modifying the regulatory pathways of angiogenesis, or indirectly by clearing pro-angiogenic factors, by blocking the signaling pathways of these factors. Endostatin, an internal fragment of type XVIII collagen (O'Reilly et al. 1997), impairs EC adhesion and migration, and interactions between cells and cellular matrix (Dixelius et al. 2002). Angiostastin, a cleavage product of plasminogen is able to bind to EC adhesion proteins, such as integrins, and to inhibit EC proliferation and migration (Troyanovsky et al. 2001). Another antiangiogenic factor, trombospondin-1, acts directly inhibiting on EC migration, inducing EC apoptosis or indirectly modulating the effects of various proangiogenic factors (Zhang and Lawler 2007).

\section{Cell types involved in neovascularization}

In addition to ECs, which are involved in neovascularization, other cells such as EPCs are critical to this process as described above. EPCs may be analogous to the embryonic angioblasts, in a sense that they can circulate, proliferate, and participate in the development of vascular networks by differentiating into mature ECs (Rafii 2000). Many animal studies have now demonstrated that bone marrow-derived cells may play a role in physiological and pathological growth in the adult, both by promoting angiogenesis through the secretion of angiogenic factors and by providing a rich source of progenitor cells that can circulate and differentiate into mature vascular ECs. Recent works implicate EPCs in healing processes of injured tissues including myocardial ischemia and infarction, limb ischemia, wound healing, atherosclerosis, endogenous endothelial repair, and tumor vascularization (for review see Hillen and Griffoioen 2007, Napoli et al. 2007). Thus, when these cells are injected into animal models with ischemia, they are rapidly incorporated into sites of neovascularization (Luttun et al. 2002).
An inverse correlation between the number of circulating EPCs and risk factors for cardiovascular disease has been reported (Hill et al. 2003, SchmidtLucke et al. 2005). In addition, these authors have found that EPCs from high-risk subjects become senescent more rapidly than those from low-risk subjects. Under these conditions, EPCs may have important vascular clinical applications. Thus, EPCs may provide an opportunity for therapeutic intervention during ischemic complications either through enhancement of the mobilization, migration, or incorporation of endogenous EPCs or through transplantation of exogenous cell populations that have been expanded ex vivo.

Under another pathologic context such as tumors, EPCs have been detected at increased frequency in the circulation of cancer patients. Also, tumor production of VEGF was found to correlate with EPC mobilization (for review see Rafii et al. 2002). During tumor development, the inhibition of the recruitment of EPCs might provide a novel approach to block tumor angiogenesis.

Taken together, mobilization of EPC might have beneficial effects on pathologies associated with ischemic complications, whereas their effects can be deleterious in cancers.

\section{Plasma membrane microparticles (MP)}

All cell types subjected to chemical, physical activation (thrombin, endotoxin or shear stress, respectively) or apoptosis (growth factor deprivation or apoptotic inducers) can virtually release plasma membrane fragments, called microparticles (MP), originally described as inert "cell dust". MP are small (0.1-1 $\mu \mathrm{m})$ membrane-bound vesicles that circulate in the blood and can mediate inflammation and thrombosis (Martinez et al. 2005). The mechanisms of MP formation are complex and not completely elucidated. Briefly, following cell activation or apoptosis, MP formation is dependent on a sustained rise in the cytosolic calcium concentration with the consequent activation of calpain and protein kinases and phosphatase inhibition. These changes result in cytoskeletal reorganization, membrane blebbing and the formation of MP (Wiedmer and Sims 1991, Yano et al. 1994, Miyazaki et al. 1996). The most abundant MP in the blood are generated from platelets, although MP in the periphery can also arise from leukocytes, erythrocytes, and cells that compose the vessel wall, mainly macrophages, ECs and smooth 
muscle cells. MP contain membrane, cytoplasmic and nuclear constituents characteristic of their precursor cells and differ in size and composition from other subcellular structures such as exosomes (Distler et al. 2005). Indeed, on the surface, MP bear antigens characteristic of the cell from which they originated allowing their characterization. Thus, functional adhesion complexes such as glycoprotein IIb-IIIa and P-selectin are harbored by MP from platelets (Baj-Krzyworzeka et al. 2002). MP of endothelial origin carry CD31 or CD146, whereas $\mathrm{CD} 4, \mathrm{CD} 3$, or CD8 is present at the surface membrane of leukocytic MP (Mallat et al. 2000, Martin et al. 2004). A large body of data implicates MP in the initiation and amplification of the coagulation cascade, in thrombosis and in the propagation of inflammation, modulation of vascular tone, angiogenesis, stem cell engraftment, tumor metastasis owing to molecules harbored at their surface or within their cytoplasm (for review see Martinez et al. 2005) suggesting that MP can be efficient vectors of biological information from one cell type to another and hence, it has been proposed that MP may account for long-range intercellular communication. Most of these processes are associated with alterations of hemostatic parameters and vascular dysfunction including attenuation of endothelium-dependent vasodilatation, alteration of responsiveness of vascular smooth muscle to vasoconstrictor stimuli or both.

\section{MP and in vitro angiogenesis}

MP can be generated in vitro from cultured cells or from human freshly isolated leukocytes or platelets. This type of preparation of MP allows studying the specific role of each type of MP depending on its cellular origin as well as the stimuli used for their generation. Indeed, it has been described that the surface markers on MP depends on the stimulus, and the response they elicit in target cells may vary accordingly (Baj-Krzyworzeka et al. 2002, Martinez et al. 2006).

Concerning the effects of MP on angiogenesis, contradictory data are reported in the literature (Fig. 1). Endothelial MP have been described as pro-angiogenic through the metalloproteinase (MMP) activity, mainly MMP-2 and MMP-9, that they harbor (Taraboletti et al. 2002). Since MMPs are involved in EC invasion and formation of capillaries, MP may promote matrix degradation and favor new vessel formation. By contrast, Mezentsev et al. (2005) have reported that endothelial MP decrease formation of capillary-like structures by increasing the production of reactive oxygen species. Thus, using a superoxide dismutase mimetic in order to neutralize reactive oxygen species, these authors have shown that angiogenesis impaired by endothelial MP was restored. The differences observed between the two studies could be related to the different concentrations of MP used. In particular, low concentrations of endothelial MP could promote angiogenesis, whereas high concentrations could suppress angiogenesis.

Platelet-derived MPs display a pro-angiogenic activity. In particular, this type of MP is able to favor almost all the steps involved in angiogenesis (proliferation, survival, migration and formation of capillary-like structures in ECs) (Kim et al. 2004). In addition, platelet MP effects on angiogenesis are mediated by phosphoinositide 3-kinase (PI3-kinase) and extracellular signal-regulated kinase (ERK) pathways. Accordingly, Brill et al. (2005) have shown that MP from platelets induced in vitro sprouting in aortic rings via PI3kinase and ERK pathways involving growth factors such as VEGF and PDGF, and also displayed in vivo effects (see below).

Recently, it has been shown that lymphocytederived MP generated in vitro after actinomycin D treatment strongly suppressed aortic ring microvessel sprouting. This effect is linked to a down-regulation of the VEGF receptor type 2 and an increase of reactive oxygen species production associated with NADPH oxidase activity (Yang et al. 2008). Also, these MP impair vascular survival, proliferation, and migration. Although these authors have not studied the potential role of NO in their study, we have shown that the same type of MP decreased NO production via the PI3-kinase pathway (Mostefai et al. 2008). Indeed, incubation of ECs with this type of MP decreased NO production that was associated with enhanced phosphorylation of eNOS on its inhibitory site and overexpression of caveolin-1. In addition, we have observed that MP enhanced reactive oxygen species by a mechanism sensitive to xanthine oxidase inhibitor. Thus, lymphocyte-derived MP generated in vitro after actinomycin $\mathrm{D}$ treatment activate pathways related to NO and reactive oxygen species productions through PI3-kinase, xanthine oxidase and NADPH oxidase (Mostefai et al. 2008, Yang et al. 2008). Since NO plays a key role in angiogenesis, one can hypothesized that in parallel to reactive oxygen speciesmediated MP effects on angiogenesis (Yang et al. 2008), the decrease of NO production induced by lymphocytederived MPs on ECs (Mostefai et al. 2008) may also be 
involved in the impairment of angiogenesis. On the other hand, we have observed that when MP are generated from apoptotic/stimulated human lymphocytes, they promote angiogenesis through the increase of proangiogenic factor expression, such as VEGF, IL-1 $\beta$ and ICAM-1 (Martinez \& Andriantsitohaina, unpublished results). These MP have the particularity to harbor at their surface the morphogen Sonic Hedgehog (Shh) (Martínez et al. 2006), which has been reported to act indirectly on angiogenesis by upregulating two families of angiogenic growth factors, VEGF and angiopoietins (Pola et al., 2001). In addition, we have shown that MP carrying Shh are able to stimulate NO production from ECs by direct activation of the Shh and PI3-kinase pathways (Agouni et al. 2007). Altogether, and depending on the stimuli used for formation of MP derived from lymphocytes, MP could represent potential tools to modulate angiogenesis. Indeed, pro-angiogenic effects of lymphocyte-derived MP are associated with their ability to release NO from ECs, whereas anti-angiogenic effects are linked to oxidative stress and reduced NO release from ECs.

\section{MP and pathologies associated with modifications in angiogenesis}

During myocardial infarction, ischemia/ reperfusion evoke deleterious consequences on the level of the myocardium, but also on coronary artery mainly at the level of the endothelium. The endothelial dysfunction described under these conditions is characterized by an impaired endothelium-dependent vasodilatation, an exaggerated endothelium-dependent vasoconstriction, increased production of endothelin-1 and reactive oxygen species leading to increase vasoconstriction and reduction of blood flow, then the endothelium becomes dysfunctional and NO formation decreases (Moens et al. 2005). In parallel, it has been described that circulating levels of MP, mainly from platelets and endothelial cells, are increased in patients with myocardial infarction (Bernal-Mizrachi et al. 2003, Zielinska et al. 2005, van der Zee et al. 2006). In addition, MP from patients with myocardial infarction impair endothelial NO transduction pathway, suggesting that MP may account, at least partially, for the endothelial dysfunction observed in these patients (Boulanger et al. 2001). New therapeutic approaches in myocardial infarction try to decrease the deleterious effects of ischemia/reperfusion, to avoid the expansion of the necrotic infarct zone and to favor neovascularization. For the later, multiple studies performed in animal models corroborate that the stimulation of collateral vessel development may have a clinical potential. Direct infusion of ischemia zone with growth factors or administration of a plasmid vector incorporating VEGF into arteries increases the formation of collateral vessels (Morishita et al. 1999, Isner et al. 1996). Recently, it has been shown that, in rat chronic ischemic heart, injection of MP from platelets into the myocardium increased the number of functioning capillaries (Brill et al. 2005), suggesting that in this pathological state, local application of MP may play an important role in controlling formation of new vessels. With regard to the correction of coronary endothelial dysfunction following cardiac ischemia/reperfusion, we found that i.v. injection of engineered MP from human activated/apoptotic $\mathrm{T}$ lymphocytes carrying Shh improved endothelial function and prevented endothelial dysfunction via NO release. It was recently reported that Shh gene therapy may have considerable therapeutic potential by improving cardiac function in either ischemia or infarct models and wound healing in diabetes (Kusano et al. 2005, Asai et al. 2006). Our data lead us to advance the hypothesis that generation of MP harboring Shh from $\mathrm{T}$ cells (and the biological message they carry) may represent a new therapeutic approach, independent of gene therapy, by which we can correct cardiovascular pathologies linked to endothelial dysfunction, and probably improve neovascularization.

In diabetes, angiogenesis is also altered. Diabetes-associated vascular complications are generally the major clinical problems, which should be treated in diabetic patients, contributing to the significant morbidity and mortality. Thus, diabetic patients have an elevated incidence of macrovascular complications, such as atherosclerosis that increases the risk for myocardial infarction, stroke, and peripheral artery disease (often leading to limb amputation), as well as microvascular complications that consist of retinopathy and nephropathy, causing blindness and renal failure (Wild et al. 2004). Elevated number of total MP, and those from platelets, lymphocytes and ECs, has been detected in diabetic patients (Sabatier et al. 2002). While platelet MP are elevated in rats with streptozotocin-induced diabetic nephropathy (Kobayashi et al. 2008), levels of monocytederived MP are increased in patients with diabetic retinopathy (Ogata et al. 2006). Altogether these findings suggest that MP may play a role in the pathogenesis of several symptoms associated with diabetes. Thus, the treatment of peripheral artery disease or retinopathy and 


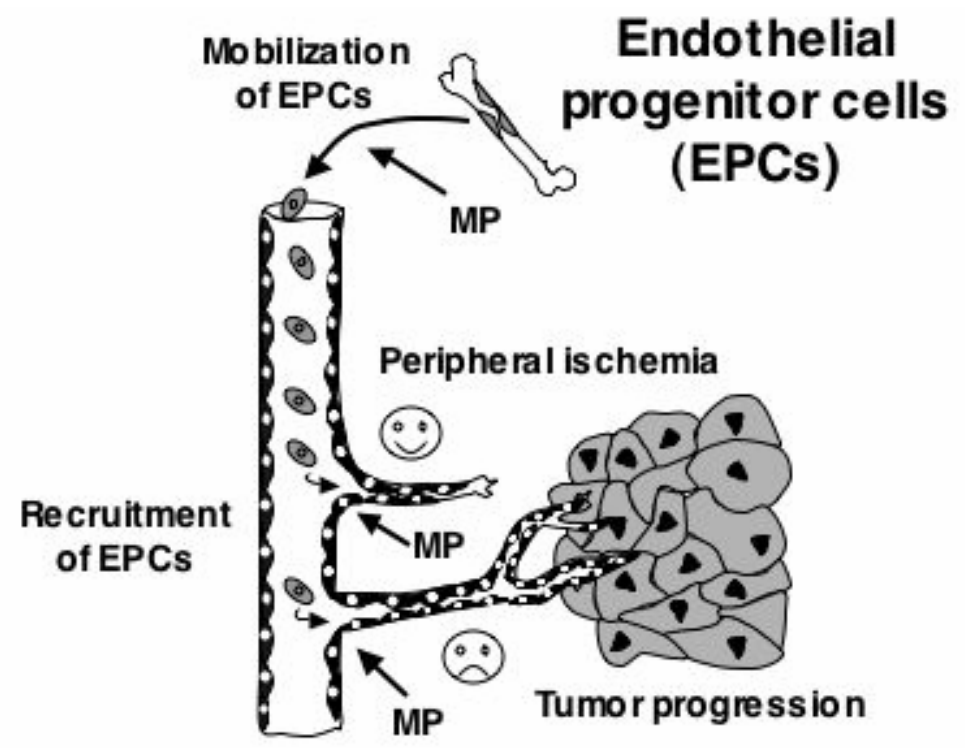

Fig. 2. Endothelial progenitor cells are involved in neovascularization. Mobilization of endothelial progenitor cells from bone marrow is induced under several conditions such as peripheral ischemia or cancer. Whereas in diseases associated with ischemia, endothelial progenitor cells may have a beneficial role and favor new blood vessel formation in order to repair tissues, during tumor development endothelial progenitor cell mobilization and recruitment may have a deleterious role promoting tumor progression. Microparticles (MP) may modulate the mobilization and recruitment of endothelial progenitor cells.

nephropathy may favor or inhibit angiogenesis, respectively. It has been shown that, in a mice model of type 2 diabetes, a plasmid DNA encoded VEGF improved blood flow after femoral artery ligation and increased VEGF protein, suggesting that gene transfer of pro-angiogenic factors are able to promote therapeutic angiogenesis in type 2 diabetes (Li et al. 2007). By contrast, anti-angiogenic therapy may be used in therapy for retinopathy and nephropathy in diabetes since recent data have shown that VEGF is, at least partially, responsible for these pathologies (Andreoli and Miller 2007, Zent and Pozzi 2006).

Finally, cancer progression is dependent on abnormal angiogenesis, in particular, exacerbated neovascularization form new vessels that guarantee an adequate supply of nutrients, oxygen, and growth factors to facilitate the growth tumor and metastasis development (Folkman 1995). Tumor cells are able to generated MP both in vitro and in vivo. Through proteins, such as urokinase, CD147 or sphingomyelin, harbored by MP from tumor cells, MP can modify the adhesive and invasive properties of tumor target cells (Angelucci et al. 2000), or the angiogenic activity of ECs (Millimaggi et al. 2007). Moreover, it has been shown that platelet MP enhance the in vitro invasive potential of breast cancer cell lines, and induce metastasis and angiogenesis in lung cancer (Janowska-Wieczorek et al. 2005, 2006). Indeed, injection of platelet MP resulted in metastatic foci in lung mice (Janowska-Wieczorek et al. 2005). These data suggest that MP transfer a transcellular signal that could allow tumor progression. Also, MP may represent a sign of vascular complications in patients with lung and gastric cancer (Kanazawa et al. 2003, Kim et al. 2003). These authors have reported enhanced circulating monocyte- and plateletderived MP in patients with lung cancer. In addition, levels of P-selectin associated to platelet MP and tissue factor generated from cancer cells are increased indicating that proteins involved in hemostasis are elevated in patients with cancer (Yu and Rak 2004) and may represent a tool for exacerbated thrombosis.

\section{Future directions}

During last years, EPCs have been considered as the key cells implicated in neovascularization. Modulation of their mobilization from bone marrow, or of their recruitment on the ischemic zones during ischemia or in zones contributing to tumor progression may represent novel potential therapeutic strategies by increasing pro-angiogenic EPC properties in ischemia or by decreasing them in cancer (Fig. 2).

Very recently, it has been reported that endothelial MP modulate angiogenic properties of EPCs in vitro (Lacroix et al. 2007). These authors have demonstrated that endothelial MP expressing urokinasetype plasminogen activator and its receptor at their surface affect tube formation mediated by EPCs. Furthermore, Deregibus et al. (2007) have shown that MP derived from EPCs are incorporated in ECs by interacting with integrins. Once this interaction takes place these MP promote the formation of in vitro capillary-like structures, which is abolished in the presence of RNase. Analysis of mRNA extract from MP showed that they carried cellular mRNA associated with the PI3-kinase/Akt signaling pathway, which plays an important role in the angiogenic effect of MP (Deregibus et al. 2007). These findings 
underline the potential role of MP in the modulation of the angiogenic program in ECs via the transfer of a biological message through mRNA delivery.

Although all of these studies have been performed in vitro, they indicate that modulation of neovascularization through direct action on both ECs or EPCs via MP interaction with these cells may represent new therapeutic tool in pathologies with alterations in neovascularization.

\section{Conflict of Interest}

There is no conflict of interest.

\section{Acknowledgements}

This work is supported by the Fondation de France ( ${ }^{\circ}$ 032144/2007001918). H.A.M. is a recipient of a doctoral fellowship from Conseil Régional du Pays de la Loire.

\section{References}

AGOUNI A, MOTEFAI AH, PORRO C, CARUSIO N, FAVRE J, RICHARD V, HENRION D, MARTINEZ MC, ANDRIANTSITOHAINA R: Sonic hedgehog carried by microparticles corrects endothelial injury through nitric oxide release. FASEB J 21: 2735-2741, 2007.

ANDREOLI CM, MILLER JW: Anti-vascular endothelial growth factor therapy for ocular neovascular disease. Curr Opin Ophthalmol. 18: 502-508, 2007.

ANGELUCCI A, D'ASCENZO S, FESTUCCIA C, GRAVINA GL, BOLOGNA M, DOLO V, PAVAN A: Vesicleassociated urokinase plasminogen activator promotes invasion in prostate cancer cell lines. Clin Exp Metastasis 18: 163-170, 2000.

ASAHARA T, MUROHARA T, SULLIVAN A, SILVER M, VAN DER ZEE R, LI T, WITZENBICHLER B, SCHATTEMAN G, ISNER JM: Isolation of putative progenitor endothelial cells for angiogenesis. Science 275: 964-967, 1997.

ASAHARA T, TAKAHASHI T, MASUDA H, KALKA C, CHEN D, IWAGURO H, INAI Y, SILVER M, ISNER JM: VEGF contributes to postnatal neovascularization by mobilizing bone marrow-derived endothelial progenitor cells. EMBO J 18: 3964-3972, 1999.

ASAI J, TAKENAKA H, KUSANO KF, II M, LUEDEMANN C, CURRY C, EATON E, IWAKURA A, TSUTSUMI Y, HAMADA H, KISHIMOTO S, THORNE T, KISHORE R, LOSORDO DW: Topical sonic hedgehog gene therapy accelerates wound healing in diabetes by enhancing endothelial progenitor cell-mediated microvascular remodeling. Circulation 113: 2413-2424, 2006.

BAJ-KRZYWORZEKA M, MAJKA M, PRATICO D, RATAJCZAK J, VILAIRE G, KIJOWSKI J, RECA R, JANOWSKA-WIECZOREK A, RATAJCZAK MZ: Platelet-derived microparticles stimulate proliferation, survival, adhesion, and chemotaxis of hematopoietic cells. Exp Hematol. 30: 450-459, 2002.

BERNAL-MIZRACHI L, JY W, JIMENEZ JJ, PASTOR J, MAURO LM, HORSTMAN LL, DE MARCHENA E, AHN YS: High levels of circulating endothelial microparticles in patients with acute coronary syndromes. $A m$ Heart J 145: 962-970, 2003.

BOULANGER CM, SCOAZEC A, EBRAHIMIAN T, HENRY P, MATHIEU E, TEDGUI A, MALLAT Z: Circulating microparticles from patients with myocardial infarction cause endothelial dysfunction. Circulation 104: 2649-2652, 2001.

BRILL A, DASHEWSKY O, RIVO J, GOZAL Y, VARON D: Platelet-derived microparticles induce angiogenesis and stimulate post-ischemic revascularization. Cardiovasc Res 67: 30-38, 2005.

CARMELIET P: Angiogenesis in health and disease. Nat Med 9: 653-660, 2003.

DAS SK, VASUDEVAN DM: Essential factors associated with hepatic angiogenesis. Life Sci 81: 1555-1564, 2007.

DEREGIBUS MC, CANTALUPPI V, CALOGERO R, LO IACONO M, TETTA C, BIANCONE L, BRUNO S, BUSSOLATI B, CAMUSSI G: Endothelial progenitor cell derived microvesicles activate an angiogenic program in endothelial cells by a horizontal transfer of mRNA. Blood 110: 2440-2448, 2007.

DISTLER JH, PISETSKY DS, HUBER LC, KALDEN JR, GAY S, DISTLER O: Microparticles as regulators of inflammation: novel players of cellular crosstalk in the rheumatic diseases. Arthritis Rheum 52: 3337-3348, 2005. 
DIXELIUS J, CROSS M, MATSUMOTO T, SASAKI T, TIMPL R, CLAESSON-WELSH L: Endostatin regulates endothelial cell adhesion and cytoskeletal organization. Cancer Res 62: 1944-1947, 2002.

DONNINI S, ZICHE M: Constitutive and inducible nitric oxide synthase: role in angiogenesis. Antioxid Redox Signal 4: 817-823, 2002.

FOLKMAN J: Angiogenesis in cancer, vascular, rheumatoid and other disease. Nat Med 1: 27-31, 1995.

FUKUHARA S: Monocyte-derived microparticles may be a sign of vascular complication in patients with lung cancer. Lung Cancer 39: 145-149, 2003.

FUKUMURA D, GOHONGI T, KADAMBI A, IZUMI Y, ANG J, YUN CO, BUERK DG, HUANG PL, JAIN RK: Predominant role of endothelial nitric oxide synthase in vascular endothelial growth factor-induced angiogenesis and vascular permeability. Proc Natl Acad Sci USA 98: 2604-2609, 2001.

HELISCH A, SCHAPER W: Arteriogenesis: the development and growth of collateral arteries. Microcirculation 10: 83-97, 2003.

HILL J.M., ZALOS G., HALCOX J.P.J., SCHENKE W.H., WACLAWIW M.A., QUYYUMI A.A., FINKEL T: Circulating endothelial progenitor cells, vascular function, and cardiovascular risk. $N$ Engl J Med 348: 593600, 2003.

HILLEN F, GRIFFOIOEN AW: Tumor vascularization: sprouting angiogenesis and beyond. Cancer Metastasis Rev 26: 489-502, 2007.

HSU AR, VEERAVAGU A, CAI W, HOU LC, TSE V, CHEN X: Integrin alpha(v)beta(3) antagonists for antiangiogenic cancer treatment. Recent Patents Anticancer Drug Discov 2: 143-158, 2007.

ISNER JM, WALSH K, SYMES J, PIECZEK A, TAKESHITA S, LOWRY J, ROSENFIELD K, WEIR L, BROGI E, JURAYJ D: Arterial gene transfer for therapeutic angiogenesis in patients with peripheral artery disease. Hum Gene Ther 7: 959-988, 1996.

JANOWSKA-WIECZOREK A, MARQUEZ-CURTIS LA, WYSOCZYNSKI M, RATAJCZAK MZ: Enhancing effect of platelet-derived microvesicles on the invasive potential of breast cancer cells. Transfusion 46: 1199-209, 2006.

JANOWSKA-WIECZOREK A, WYSOCZYNSKI M, KIJOWSKI J, MARQUEZ-CURTIS L, MACHALINSKI B, RATAJCZAK J, RATAJCZAK MZ: Microvesicles derived from activated platelets induce metastasis and angiogenesis in lung cancer. Int $J$ Cancer 113: 752-760, 2005.

KANAZAWA S, NOMURA S, KUWANA M, MURAMATSU M, YAMAGUCHI K, FUKUHARA S: Monocytederived microparticles may be a sign of vascular complication in patients with lung cancer. Lung Cancer 39: 145-149, 2003.

KIM CW, LEE HM, LEE TH, KLEINMAN HK, GHO YS: Extracellular membrane vesicles from tumor cells promote angiogenesis via sphingomyelin. Cancer Res 62: 6312-6317, 2002.

KIM HK, SONG KS, PARK YS, KANG YH, LEE YJ, LEE KR, KIM HK, RYU KW, BAE JM, KIM S: Elevated levels of circulating platelet microparticles, VEGF, IL-6 and RANTES in patients with gastric cancer: possible role of a metastasis predictor. Eur J Cancer 39: 184-191, 2003.

KIM HK, SONG KS, CHUNG JH, LEE KR, LEE SN: Platelet microparticles induce angiogenesis in vitro. $\mathrm{Br} J$ Haematol 124: 376-384, 2004.

KOBAYASHI S, SATOH M, NAMIKOSHI T, HARUNA Y, FUJIMOTO S, ARAKAWA S, KOMAI N, TOMITA N, SASAKI T, KASHIHARA N: Blockade of serotonin 2A receptor improves glomerular endothelial function in rats with streptozotocin-induced diabetic nephropathy. Clin Exp Nephrol 12: 119-125, 2008.

KUSANO KF, POLA R, MURAYAMA T, CURRY C, KAWAMOTO A, IWAKURA A, SHINTANI S, II M, ASAI J, TKEBUCHAVA T, THORNE T, TAKENAKA H, AIKAWA R, GOUKASSIAN D, VON SAMSON, HAMADA H, YOON YS, SILVER M, EATON E, MA H, HEYD L, KEARNEY M, MUNGER W, PORTER JA, KISHORE R, LOSORDO DW: Sonic hedgehog myocardial gene therapy: tissue repair through transient reconstitution of embryonic signaling. Nature Med 11: 1197-1204, 2005.

LACROIX R, SABATIER F, MIALHE A, BASIRE A, PANNELL R, BORGHI H, ROBERT S, LAMY E, PLAWINSKI L, CAMOIN-JAU L, GUREWICH V, ANGLES-CANO E, DIGNAT-GEORGE F: Activation of plasminogen into plasmin at the surface of endothelial microparticles: a mechanism that modulates angiogenic properties of endothelial progenitor cells in vitro. Blood. 110: 2432-2439, 2007. 
LI Y, HAZARIKA S, XIE D, PIPPEN AM, KONTOS CD, ANNEX BH: In mice with type 2 diabetes, a vascular endothelial growth factor (VEGF)-activating transcription factor modulates VEGF signaling and induces therapeutic angiogenesis after hindlimb ischemia. Diabetes 56: 656-665, 2007.

LUQUE CONTRERAS D, VARGAS ROBLES H, ROMO E, RIOS A, ESCALANTE B: The role of nitric oxide in the post-ischemic revascularization process. Pharmacol Ther 112: 553-563, 2006.

LUTTUN A., CARMELIET G., CARMELIET P: Vascular progenitors: from biology to treatment. Trends Cardiovasc Med 12: 88-96, 2002.

MALLAT Z, BENAMER H, HUGEL B, BENESSIANO J, STEG PG, FREYSSINET JM, TEDGUI A: Elevated levels of shed membrane microparticles with procoagulant potential in the peripheral circulating blood of patients with acute coronary syndromes. Circulation 101: 841-843, 2000.

MARTIN S, TESSE A, HUGEL B, MARTINEZ MC, MOREL O, FREYSSINET JM, ANDRIANTSITOHAINA R: Shed membrane particles from $\mathrm{T}$ lymphocytes impair endothelial function and regulate endothelial protein expression. Circulation 109: 1653-1659, 2004.

MARTINEZ MC, LARBRET F, ZOBAIRI F, COULOMBE J, DEBILI N, VAINCHENKER W, RUAT M, FREYSSINET JM: Transfer of differentiation signal by membrane microvesicles harbouring hedgehog morphogens. Blood 108: 3012-3020, 2006.

MARTINEZ MC, TESSE A, ZOBAIRI F, ANDRIANTSITOHAINA R: Shed membrane microparticles from circulating and vascular cells in regulating vascular function. Am J Physiol 288: H1004-H1009, 2005.

MEZENTSEV A, MERKS RM, O'RIORDAN E, CHEN J, MENDELEV N, GOLIGORSKY MS, BRODSKY SV: Endothelial microparticles affect angiogenesis in vitro: role of oxidative stress. Am J Physiol 289: H1106H1114, 2005.

MILLIMAGGI D, MARI M, D'ASCENZO S, CAROSA E, JANNINI EA, ZUCKER S, CARTA G, PAVAN A, DOLO V: Tumor vesicle-associated CD147 modulates the angiogenic capability of endothelial cells. Neoplasia 9: 349-357, 2007.

MIYAZAKI Y, NOMURA S, MIYAKE T, KAGAWA H, KITADA C, TANIGUCHI H, KOMIYAMA Y, FUJIMURA Y, IKEDA Y, FUKUHARA S: High shear stress can initiate both platelet aggregation and shedding of procoagulant containing microparticles. Blood 88: 3456-3464, 1996.

MOENS AL, GOOVAERTS I, CLAEYS MJ, VRINTS CJ: Flow-mediated vasodilation: a diagnostic instrument, or an experimental tool? Chest 127: 2254-2263, 2005.

MORISHITA R, NAKAMURA S, HAYASHI S, TANIYAMA Y, MORIGUCHI A, NAGANO T, TAIJI M, NOGUCHI H, TAKESHITA S, MATSUMOTO K, NAKAMURA T, HIGAKI J, OGIHARA T: Therapeutic angiogenesis induced by human recombinant hepatocyte growth factor in rabbit hind limb ischemia model as cytokine supplement therapy. Hypertension 33: 1379-1384, 1999.

MOSTEFAI AH, AGOUNI A, CARUSIO N, MASTRONARDI L, HEYMES C, HENRION D, ANDRIANTSITOHAINA R., MARTINEZ MC: PI3-Kinase and xanthine oxidase regulate NO and reactive oxygen species production by apoptotic lymphocyte microparticles in endothelial cells. J Immunol 180: 50285035, 2008.

MOTRO B, ITIN A, SACHS L, KESHET E: Pattern of interleukin 6 gene expression in vivo suggests a role for this cytokine in angiogenesis. Proc Natl Acad Sci USA 87: 3092-3096, 1990.

NAPOLI C, BALESTRIERI A, IGNARRO LJ: Therapeutic approaches in vascular repair by adult bone marrow cells and circulating progenitor endothelial cells. Curr Pharm Des 13: 3245-3251, 2007.

OGATA N, NOMURA S, SHOUZU A, IMAIZUMI M, ARICHI M, MATSUMURA M: Elevation of monocytederived microparticles in patients with diabetic retinopathy. Diabetes Res Clin Pract 73: 241-248, 2006.

O'REILLY MS, BOEHM T, SHING Y, FUKAI N, VASIOS G, LANE WS, FLYNN E, BIRKHEAD JR, OLSEN BR, FOLKMAN J: Endostatin: an endogenous inhibitor of angiogenesis and tumor growth. Cell 88: 277-285, 1997.

PARK CC, MOREL JC, AMIN MA, CONNORS MA, HARLOW LA, KOCH AE: Evidence of IL-18 as a novel angiogenic mediator. J Immunol. 167: 1644-1653, 2001.

PEPPER MS: Role of the matrix metalloproteinase and plasminogen activator-plasmin systems in angiogenesis. Arterioscler Thromb Vasc Biol 21: 1104-1117, 2001. 
POLA R, LING LE, SILVER M, CORBLEY MJ, KEARNEY M, BLAKE PEPINSKY R, SHAPIRO R, TAYLOR FR, BAKER DP, ASAHARA T. ISNER JM: The morphogen Sonic hedgehog is an indirect angiogenic agent upregulating two families of angiogenic growth factors. Nat Med 7: 706-711, 2001.

RAFII S: Circulating endothelial precursors: mystery, reality, and promise. J Clin Invest 105: 17-19, 2000.

RAFII S, LYDEN D, BENEZRA R, HATTORI K, HEISSIG B: Vascular and haematopoietic stem cells: novel targets for anti-angiogenesis therapy. Nat Rev Cancer 2: 826-835, 2002.

SABATIER F, DARMON P, HUGEL B, COMBES V, SANMARCO M, VELUT JG, ARNOUX D, CHARPIOT P, FREYSSINET JM, OLIVER C, SAMPOL J, DIGNAT-GEORGE F: Type 1 and type 2 diabetic patients display different patterns of cellular microparticles. Diabetes 51: 2840-2845, 2002.

SCMIDT-LUCKE C, ROSSIG L, FICHTLSCHERER S, VASA M, BRITTEN M, KAMPER U, DIMMELER S, ZEIHER AM: Reduced number of circulating endothelial progenitor cells predicts future cardiovascular events: proof of concept for the clinical importance of endogenous vascular repair. Circulation 111: 29812987, 2005.

SIMS PJ, WIEDMER T: The response of human platelets to activated components of the complement system. Immunol Today 12: 338-42, 1991.

TARABOLETTI G, D'ASCENZO S, BORSOTTI P, GIAVAZZI R, PAVAN A, DOLO V: Shedding of the matrix metalloproteinases MMP-2, MMP-9, and MT1-MMP as membrane vesicle-associated components by endothelial cells. Am J Pathol 160: 673-680, 2002.

TROYANOVSKY B, LEVCHENKO T, MÅNSSON G, MATVIJENKO O, HOLMGREN L: Angiomotin: an angiostatin binding protein that regulates endothelial cell migration and tube formation. $J$ Cell Biol 152: 12471254. 2001.

VAN DER ZEE PM, BIRÓ E, KO Y, DE WINTER RJ, HACK CE, STURK A, NIEUWLAND R: P-selectin- and CD63exposing platelet microparticles reflect platelet activation in peripheral arterial disease and myocardial infarction. Clin Chem 52: 657-664, 2006.

WIEDMER T, SIMS PJ: Participation of protein kinases in complement C5b-9-induced shedding of platelet plasma membrane vesicles. Blood 78: 2880-2886, 1991.

WILD S, ROGLIC G, GREEN A, SICREE R, KING H: Global prevalence of diabetes: estimates for the year 2000 and projections for 2030. Diabetes Care 27: 1047-1053, 2004.

YANG C, MWAIKAMBO BR, ZHU T, GAGNON C, LAFLEUR J, SESHADRI S, LACHAPELLE P, LAVOIE JC, CHEMTOB S, HARDY P: Lymphocytic microparticles inhibit angiogenesis by stimulating oxidative stress and negatively regulating VEGF-induced pathways. Am J Physiol 294: R467-R476, 2008.

YANO Y, KAMBAYASHI J, SHIBA E, SAKON M, OIKI E, FUKUDA K, KAWASAKI T, MORI T: The role of protein phosphorylation and cytoskeletal reorganization in microparticle formation from the platelet plasma membrane. Biochem J 299: 303-308, 1994.

YU JL, RAK JW: Shedding of tissue factor (TF)-containing microparticles rather than alternatively spliced TF is the main source of TF activity released from human cancer cells. J Thromb Haemost 2: 2065-2067, 2004.

ZENT R, POZZI A. Antiangiogenic therapy in diabetic nephropathy. J Am Soc Nephrol 17: 325-327, 2006.

ZHANG X, LAWLER J: Thrombospondin-based antiangiogenic therapy. Microvasc Res 74: 90-99, 2007.

ZICHE M, MORBIDELLI L, CHOUDHURI R, ZHANG HT, DONNINI S, GRANGER HJ, BICKNELL R: Nitric oxide synthase lies downstream from vascular endothelial growth factor-induced but not basic fibroblast growth factor-induced angiogenesis. J Clin Invest 99: 2625-2634, 1997.

ZIELINSKA M, KONIAREK W, GOCH JH, CEBULA B, TYBURA M, ROBAK T, SMOLEWSKI P: Circulating endothelial microparticles in patients with acute myocardial infarction. Kardiol Pol 62: 531-542, 2005. 